\title{
$\beta$-D-Glucoside utilization by Mycoplasma mycoides subsp. mycoides SC: possible involvement in the control of cytotoxicity towards bovine lung cells
}

\author{
Edy M Vilei*1, Ivone Correia ${ }^{2}$, M Helena Ferronha ${ }^{2}$, Daniela F Bischof ${ }^{1}$ and \\ Joachim Frey ${ }^{1}$
}

Address: ${ }^{1}$ Institute of Veterinary Bacteriology, University of Bern, Länggass-Strasse 122, Postfach, CH-3001 Bern, Switzerland and ${ }^{2}$ Laboratório Nacional de Investigação Veterinária, Departamento de Biologia Celular, Estrada de Benfica 701, P-1549-011 Lisbon, Portugal

Email: Edy M Vilei* - edy.vilei@vbi.unibe.ch; Ivone Correia - ivone.correia@lniv.min-agricultura.pt; M

Helena Ferronha - helena.ferronha@Iniv.min-agricultura.pt; Daniela F Bischof - daniela.bischof@vbi.unibe.ch; Joachim Frey - joachim.frey@vbi.unibe.ch

* Corresponding author

Published: 17 April 2007

BMC Microbiology 2007, 7:31 doi:|0.||86/|47|-2|80-7-3|
Received: 22 September 2006

Accepted: 17 April 2007

This article is available from: http://www.biomedcentral.com/I47I-2/80/7/3I

(c) 2007 Vilei et al; licensee BioMed Central Ltd.

This is an Open Access article distributed under the terms of the Creative Commons Attribution License (http://creativecommons.org/licenses/by/2.0), which permits unrestricted use, distribution, and reproduction in any medium, provided the original work is properly cited.

\begin{abstract}
Background: Contagious bovine pleuropneumonia (CBPP) caused by Mycoplasma mycoides subsp. mycoides small-colony type (SC) is among the most serious threats for livestock producers in Africa. Glycerol metabolism-associated $\mathrm{H}_{2} \mathrm{O}_{2}$ production seems to play a crucial role in virulence of this mycoplasma. A wide number of attenuated strains of $M$. mycoides subsp. mycoides SC are currently used in Africa as live vaccines. Glycerol metabolism is not affected in these vaccine strains and therefore it does not seem to be the determinant of their attenuation. A non-synonymous single nucleotide polymorphism (SNP) in the bgl gene coding for the 6-phospho- $\beta$-glucosidase (Bgl) has been described recently. The SNP differentiates virulent African strains isolated from outbreaks with severe CBPP, which express the $\mathrm{Bgl}$ isoform $\mathrm{Val}_{204}$, from strains to be considered less virulent isolated from CBPP outbreaks with low mortality and vaccine strains, which express the $\mathrm{Bgl}$ isoform $\mathrm{Ala}_{204}$.
\end{abstract}

Results: Strains of $M$. mycoides subsp. mycoides SC considered virulent and possessing the Bgl isoform $\mathrm{Val}_{204}$, but not strains with the $\mathrm{Bgl}$ isoform $\mathrm{Ala}_{204}$, do trigger elevated levels of damage to embryonic bovine lung (EBL) cells upon incubation with the disaccharides (i.e., $\beta$-D-glucosides) sucrose and lactose. However, strains expressing the $\mathrm{Bgl}$ isoform $\mathrm{Val}_{204}$ show a lower hydrolysing activity on the chromogenic substrate $p$-nitrophenyl- $\beta$-D-glucopyranoside ( $\mathrm{pNPbG}$ ) when compared to strains that possess the $\mathrm{Bgl}$ isoform $\mathrm{Ala}_{204}$. Defective activity of $\mathrm{Bgl}$ in $\mathrm{M}$. mycoides subsp. mycoides $\mathrm{SC}$ does not lead to $\mathrm{H}_{2} \mathrm{O}_{2}$ production. Rather, the viability during addition of $\beta$-Dglucosides in medium-free buffers is higher for strains harbouring the $\mathrm{Bgl}$ isoform $\mathrm{Val}_{204}$ than for those with the isoform $\mathrm{Ala}_{204}$.

Conclusion: Our results indicate that the studied SNP in the bgl gene is one possible cause of the difference in bacterial virulence among strains of $M$. mycoides subsp. mycoides SC. Bgl does not act as a direct virulence factor, but strains possessing the $\mathrm{Bgl}$ isoform $\mathrm{Val}_{204}$ with low hydrolysing activity are more prone to survive in environments that contain high levels of $\beta$-D-glucosides, thus contributing in some extent to mycoplasmaemia. 


\section{Background}

Mycoplasma species are known to represent the smallest self replicating organisms on earth, possessing the smallest genomes that contain basically fundamental functions to ensure autonomous life. Potential virulence genes are found in many mycoplasmas [1-9]. However, the genome of Mycoplasma mycoides subsp. mycoides small-colony type (SC), a Mycoplasma species causing one of most severe infectious animal diseases as defined by the World Organization for Animal Health and included in the list of diseases notifiable to the Office International des Epizooties (OIE), does not show classical virulence genes such as toxin, cytolysin and invasin genes [10]. M. mycoides subsp. mycoides SC causes contagious bovine pleuropneumonia (CBPP), the most serious cattle disease in Africa since the successful control of rinderpest [11]. In Europe, CBPP reemerged at the end of the last century after being completely eradicated between 1967 and the 1980s [12], thus showing that CBPP is still a threat also to continents that have been able to eradicate the disease.

Virulence of M. mycoides subsp. mycoides SC seems to be determined by intrinsic functions such as: i) capsular polysaccharide (CPS) that seems to be involved in serumresistance [13-17]; ii) lipoproteins that are expected to play a role as triggers in mechanisms of pathogenicity and in the release of pro-inflammatory cytokines [18-22]; iii) yet unknown but necessary adhesion factors that may play a central role in the intimate interactions of pathogenic mycoplasmas with mammalian cells for long periods thus triggering a cascade of signals which are transduced to the host cell and induce inflammation [23]; iv) repeating elements in variable membrane proteins of mycoplasmas that are suggested to increase the pathogen's ability to adhere to host cells and to evade the host immune response [24-26]; v) immunomodulating factors that can cause apoptosis of the mononuclear cells triggered by live M. mycoides subsp. mycoides SC or by a substance released by these mycoplasmas [27]; and vi) toxic metabolic side products such as $\mathrm{H}_{2} \mathrm{O}_{2}$ [28-31], which is translocated efficiently to the host cells where it can cause cell death [32].

Since no genetic tools for targeted mutagenesis are available for M. mycoides subsp. mycoides SC, analysis of virulence factors requires the use of various strains, including field strains from outbreaks of CBPP with various degrees of severity, strains from geographically different areas and live vaccine strains. Detailed genetic studies comparing $M$. mycoides subsp. mycoides SC isolates has provided evidence that deletion of $g t s C$ and part of $g t s B$ (two of three genes involved in glycerol transport) in the moderately virulent European strains correlated with a reduced ability to produce $\mathrm{H}_{2} \mathrm{O}_{2}$ compared to the highly virulent strains of the African/Australian cluster [31]. Vaccine strains of $M$. mycoides subsp. mycoides SC such as T1/44, T1/Sr50 and
$\mathrm{KH}_{3} \mathrm{~J}$ possess however an intact glycerol uptake system and metabolism $[33,34]$, which do not distinguish them from virulent field strains by means of $\mathrm{H}_{2} \mathrm{O}_{2}$ production. Hence, other functions that determine virulence are expected in M. mycoides subsp. mycoides SC. For instance, these vaccine strains seem to produce lower amounts of CPS compared to field strains [16]. CPS seems to play a role in the capacity of persistence and dissemination of $M$. mycoides subsp. mycoides SC in the infected host [17]. However, the genetic locus of the CPS regulation still remains unknown.

We have recently identified by PCR amplification and restriction enzyme analysis (PCR-REA) a genetic difference in a structural gene which divides $M$. mycoides subsp. mycoides SC strains in two groups, one including virulent African field strains and the other comprising the T1derived vaccine strains $\mathrm{T} 1 / 44$ and $\mathrm{T} 1 / \mathrm{Sr} 50$, as well as European and Australian strains and the type strain PG1 [35]. This genetic difference was found in the $b g l$ gene that codes for 6-phospho- $\beta$-glucosidase (Bgl). Bgl is an enzyme that is associated with the phosphoenolpyruvatedependent sugar:phosphotransferase system (PEP-PTS), a multicomponent system involved in the simultaneous translocation and phosphorylation of sugars by bacteria from both gram-positive and gram-negative genera [36]. The PEP-PTS and Bgl are involved in incorporation and subsequent catabolism of $\beta$-D-glucosides (e.g., disaccharides).

The present work focuses on the characterization of $\mathrm{Bgl}$ and related disaccharide catabolism, and the possible contribution of sugar metabolism to control cytotoxicity of M. mycoides subsp. mycoides SC.

\section{Results \\ Genetic variability of the bgl gene in M. mycoides subsp. mycoides SC}

The $9.8 \mathrm{~kb}$ genomic region containing the genes involved in disaccharide uptake and metabolism in M. mycoides subsp. mycoides SC type strain PG1, whose genome sequence was published by Westberg et al. [10], was considered in this study. Figure 1 shows the expected roles of EIIBC, sugar hydrolase, EIIA, Bgl and Suk in the disaccharide transport system and sugar metabolism. The bgl gene from ten selected strains of M. mycoides subsp . mycoides SC (Table 1) was sequenced with primers listed in Table 2. The sequences from the African field strains Afadé, 8740 and 91130 were identical, although these strains were isolated in geographically distant locations in an interval of as much as 23 years. The $b g l$ sequences obtained from the vaccine strains $\mathrm{T} 1 / 44$ and $\mathrm{T} 1 / \mathrm{Sr} 50$, as well as from type strain PG1, two European and two Australian strains presented a single nucleotide polymorphism (SNP) when compared to those of the African field strains. The non- 
synonymous SNP involves an amino acid change at position 204 of the Bgl protein sequence reported recently [35]. The group of the three African field strains possesses the $\mathrm{Bgl}$ isoform $\mathrm{Val}_{204}$, while the vaccine strains, the European and Australian outbreak strains and PG1 possess the Bgl isoform $\mathrm{Ala}_{204}$.

\section{Carbohydrate utilization of M. mycoides subsp. mycoides SC}

The biochemical reactions of all strains tested indicated that M. mycoides subsp. mycoides SC can use the monosaccharides glucose, fructose and galactose, and the disaccharides sucrose and lactose. In fact, after incubation of mycoplasma suspensions in serum-free media with high amounts of either substrate in the presence of the indicator bromothymol blue for 6 days, all reactions turned light green to bright yellow (depending on the substrate) in colour, indicating production of $\mathrm{CO}_{2}$ and therefore carbohydrate uptake and utilization. Daily examination of the reactions revealed that there were no significant differences in the substrate utilization rates among the 5 strains tested (not shown).

\section{M. mycoides subsp. mycoides SC induction of cell damage in the presence of sugars}

The effect of M. mycoides subsp. mycoides SC on embryonic bovine lung (EBL) cells in the presence and absence of disaccharides was studied. Figure 2 shows the cell damage mediated by strain 8740 , chosen as representative of $M$. mycoides subsp. mycoides SC strains with the Bgl isoform $\mathrm{Val}_{204}$, and of the vaccine strain $\mathrm{T} 1 / 44$, as representative for strains with the $\mathrm{Bgl}$ isoform $\mathrm{Ala}_{204}$. Cell damage was expressed by morphological changes mainly characterized by cell retraction, which was evident in monolayers of EBL cells inoculated with strain 8740 in the presence of sucrose or lactose but not in EBL cells inoculated with vaccine strain $\mathrm{T} 1 / 44$, with or without these disaccharides. The relative cell damage as a measure for cytotoxicity increased with increasing concentrations of the disaccharides (not shown). Morphological changes were already noticeable $3 \mathrm{~h}$ post-inoculation with strain 8740 in the presence of low concentrations of sucrose and lactose. At $4 \mathrm{~h}$, those changes became easily observable (Figure 2, panels A and B) and were more evident at $8 \mathrm{~h}$ post-inoculation (not shown). Mycoplasmas incubated in the presence of monosaccharides for $4 \mathrm{~h}$ had no cytotoxic effects towards EBL cells (Figure 2, panel C).

After $24 \mathrm{~h}$, cell monolayers infected with strain 8740 in the presence of sucrose and lactose had almost completely lost confluence and numerous detached rounded cells were observed (Figure 2, panels D and E). Morphological cell changes after $24 \mathrm{~h}$ were also seen with strain 8740 when incubated with glucose, fructose or galactose, but the degree of cell damage mediated by these monosaccha- rides was significantly lower when compared to that of the disaccharides (Figure 2, panel F). Strain T1/44 did not induce cell damage, either in the presence or absence of the five tested sugars (Figure 2, panels G, H and I). The same was observed with the European strains L2 and B345/93 (not shown).

The cytotoxic effect observed upon incubation with strain 8740 in the presence of the disaccharides could not be blocked when the cell monolayers were pre-treated with catalase at a concentration of $160 \mathrm{U} / \mathrm{ml}$. Under these conditions, the EBL cells showed dramatic morphological changes $24 \mathrm{~h}$ post infection as in the absence of catalase (Figure 2, panel J). Strain T1/44 in the presence of disaccharides and catalase (Figure 2, panel $\mathrm{K}$ ) and catalase alone (Figure 2, panel L) did not induce cell damage. Moreover, no morphological changes were detected when EBL cell monolayers were incubated either with sugars alone, with strain 8740 alone or with axenic medium (Figure 2, panels $\mathrm{M}, \mathrm{N}$ and $\mathrm{O}$ ).

\section{pNPbG hydrolysis of M. mycoides subsp. mycoides SC grown on solid medium}

Hydrolysis of $p$-nitrophenyl- $\beta$-D-glucopyranoside (pNPbG; colourless) to give $p$-nitrophenol (yellow) was determined qualitatively to assess 6-phospho- $\beta$-glucosidase activity by flooding cultures of $M$. mycoides subsp . mycoides SC on nutrient agar plates with pNPbG solution. After $1 \mathrm{~h}$, no colour change was seen with the African $M$. mycoides subsp . mycoides SC field strains tested (Afadé, 8740 and 91130), indicating no detectable hydrolytic activity of Bgl isoform $\mathrm{Val}_{204}$. In contrast, individual colonies of the other strains tested, i.e., the vaccine strains T1/ 44 and T1/Sr50, as well as the European strains B345/93 and L2 and the Australian strains Gladysdale and DVZ, which express the $\mathrm{Bgl}$ isoform $\mathrm{Ala}_{204}$, were coloured yellow, indicating hydrolysis of pNPbG (Table 1). It has to be noted that after prolonged incubation, the three African field strains also showed some hydrolysis of pNPbG, as revealed by a light yellow coloration in areas of confluent growth.

Production of $\mathrm{H}_{2} \mathrm{O}_{2}$ by $M$. mycoides subsp. mycoides SC Production of $\mathrm{H}_{2} \mathrm{O}_{2}$ after the addition of mono- and disaccharides to suspensions of $M$. mycoides subsp . mycoides SC strain 8740 and the vaccine strain $\mathrm{T} 1 / 44$, chosen as representative strains in this study, was measured. Addition of physiological concentrations of the different sugars to the two mycoplasmas tested resulted in a weak release of $\mathrm{H}_{2} \mathrm{O}_{2}$ into the incubation buffer after $1 \mathrm{~h}$. The released $\mathrm{H}_{2} \mathrm{O}_{2}$ levels measured in the suspensions were at concentrations below or equal to $0.5 \mu \mathrm{g} / \mathrm{ml}$, the detection level of the assay. In contrast, the addition of $100 \mu \mathrm{M}$ glycerol to the mycoplasmas instantly resulted in a strong release of $\mathrm{H}_{2} \mathrm{O}_{2}$ into the incubation buffer, reaching 8.75 
A

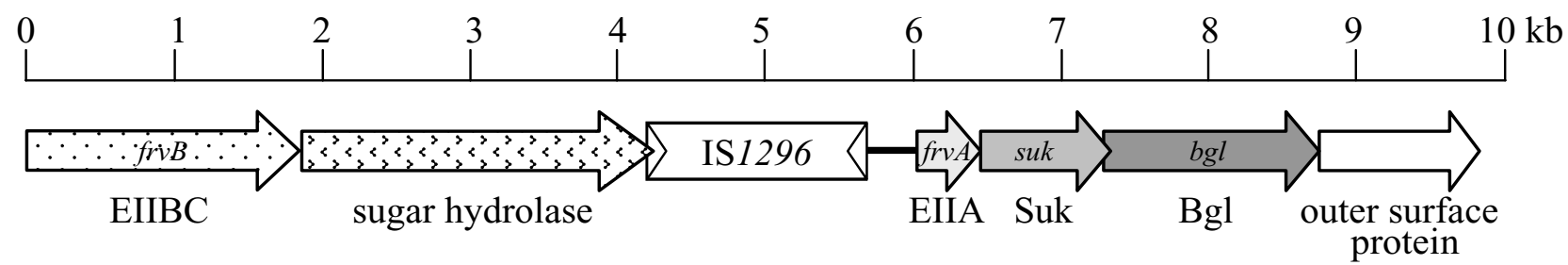

$\mathrm{B}$

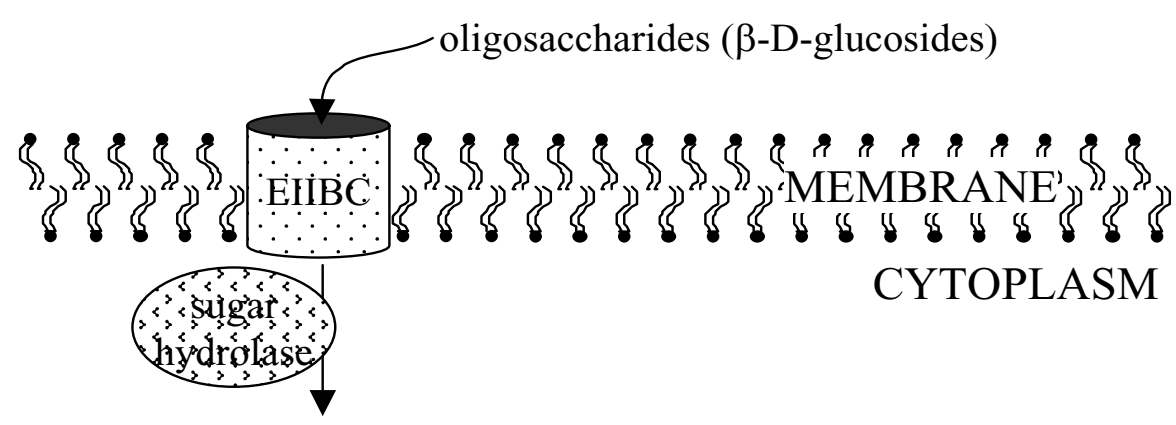

low complex $\beta$-D-glucosides

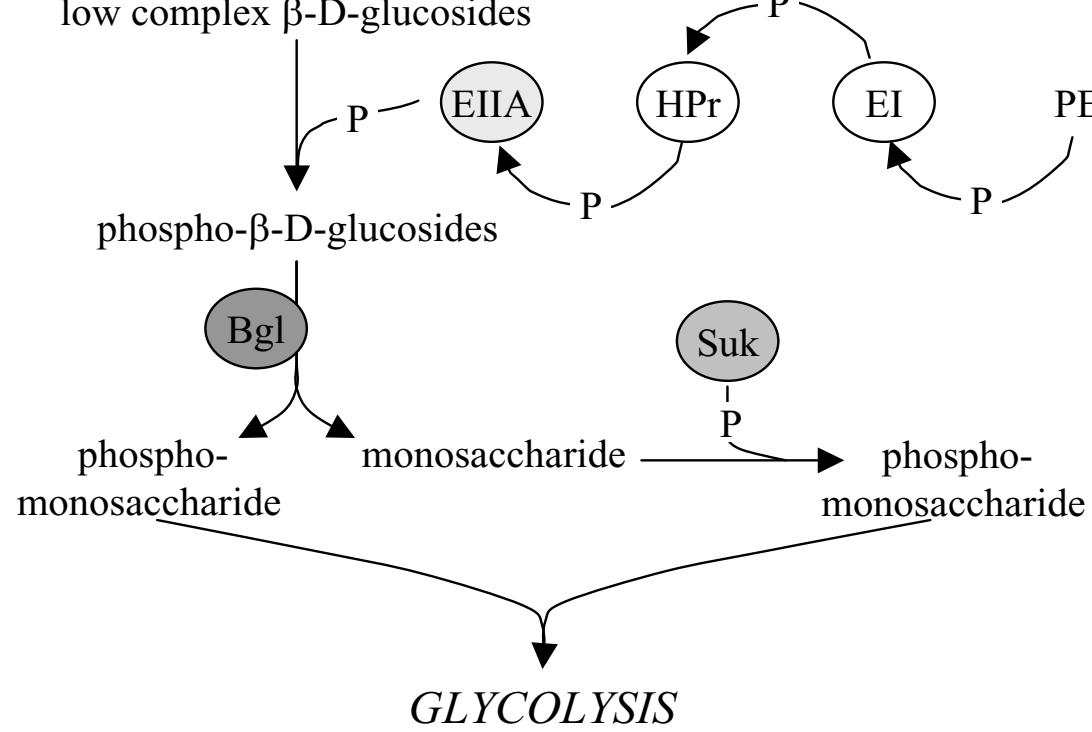

Figure I

Identification of the genes involved in oligosaccharide uptake and Bgl-dependent utilization in $M$. mycoides subsp. mycoides SC. (A) Genetic map of the locus involved in the metabolism of $\beta$-D-glucosides. The open box indicates the IS element IS 1296 and the large horizontal arrows indicate open reading frames found in the $9.8 \mathrm{~kb}$ DNA portion. (B) Model for the Bgl-dependent metabolism of $\beta$-D-glucosides in $M$. mycoides subsp. mycoides SC. Oligosaccharides are incorporated into the mycoplasma through the protein EIIBC. Once in the cytoplasm, sugar hydrolase may split complex $\beta$-D-glucosides into less complex $\beta$-D-glucosides (e.g., monosaccharides and disaccharides). Phosphorylation of these intracellular sugar molecules is preceded by the transfer of a phosphoryl group (P) from phosphoenolpyruvate (PEP) to EIIA in a pathway also involving enzyme I (EI) and the phosphoryl carrier protein (HPr). Then, Bgl hydrolyzes $\beta$-glycosidic linkages in the phospho- $\beta$-D-glucosides and residual monosaccharides are phosphorylated by the sugar kinase (Suk) before entering glycolysis. 
Table I: M. mycoides subsp. mycoides SC strains used

\begin{tabular}{|c|c|c|c|c|c|c|}
\hline Strain ${ }^{a}$ & Origin & Year Isolated & Host & Bgl SNPb & Bgl activityc & Accession number or reference ${ }^{d}$ \\
\hline PG I & Unknown & 1931 & Cattle/type strain & Ala & ND & {$[10]$} \\
\hline B345/93 & Portugal & 1993 & Cattle & Ala & + & $\underline{A M I 14901}$ \\
\hline L2 & Italy & 1993 & Cattle/lung & Ala & + & AMII4902 \\
\hline Afadé & Cameroon & 1968 & Cattle/lung & Val & - & {$[35]$} \\
\hline 8740 & Cameroon & 1987 & Cattle & Val & - & AMII4903 \\
\hline 91130 & Central African Republic & 1991 & Cattle & Val & - & $\underline{A M I 14904}$ \\
\hline TI/44 & Tanzania & 1952 & Cattle/vaccine strain & Ala & + & $\underline{A M I 14905}$ \\
\hline TI/Sr50 & Tanzania & 1952 & Cattle/vaccine strain & Ala & + & [35] \\
\hline Gladysdale & Australia & Unknown & Cattle & Ala & + & $\underline{A M I 14906}$ \\
\hline DVZ & Australia & 1965 & Cattle & Ala & + & AMII4907 \\
\hline
\end{tabular}

a Strains were obtained from National Collection of Type Cultures (NCTC), PHLS, London, United Kingdom; Laboratório Nacional de Investigação Veterinária, Lisbon, Portugal; Institute of Veterinary Bacteriology, Vetsuisse Faculty, University of Bern, Bern, Switzerland; CIRAD-EMVT,

Montpellier, France; and Australian Animal Health Laboratory, Geelong, Victoria, Australia.

${ }^{b}$ Residue at amino acid position 204 of Bgl.

cpNPbG hydrolysis within I h (yellow colonies also in the last of the six 10-fold dilutions) corresponds to Bgl activity and is represented by "+"; "-" indicates a reduced enzymatic activity of Bgl (only the areas spotted with the first two 10 -fold dilutions became yellowish, and only after $3 \mathrm{~h}$ ); ND: not done.

d Sequences of $\mathrm{bg} /$ for PGI, Afadé and TI/Sr50 were not determined in this work, as that of PGI is already available from the genome project [10] and those of Afadé and TI/Sr50 from our previous work [35].

Table 2: Oligonucleotide primers used in this study

\begin{tabular}{|c|c|c|c|c|}
\hline Primer & Sequence $\left(5^{\prime}-3^{\prime}\right)^{a}$ & Position $^{\mathrm{a}}$ & Annealing temp. $\left({ }^{\circ} \mathrm{C}\right)^{\mathrm{b}}$ & Use $^{\mathrm{c}}$ \\
\hline 4000bp-6L & TCTATATCTAATCCTGAGTTTTC & $954 \mid 52-954174$ & 50 & $P$ \\
\hline $4000 b p-8 R$ & GAACAAGGTTCAAATTGTTTTGG & $954802-954780$ & 52 & $S$ \\
\hline 4000bp-4L & CTAAATTGTCCTTTTATAACTGC & $955230-955252$ & 51 & S \\
\hline $4000 b p-5 R$ & TAAACCTTACTCCTACAATACC & $955347-955326$ & 50 & $S$ \\
\hline 4000bp-IL & ACCATCAACTAAAACTACAGG & $955499-955519$ & 50 & $\mathrm{~S}$ \\
\hline $4000 b p-3 R$ & TAGAAAATATTGGTGGTTGAAC & $955635-9556 \mid 4$ & 49 & S \\
\hline 4000bp-7L & TTAATCTTGTTCATTGAATAGAAG & $955765-955788$ & 51 & S \\
\hline 4000 bp-2R & CAGAAAATGATAGTGCAAATG & $957029-957009$ & 50 & $P$ \\
\hline IPPQTM2-L & CTAGAACTGAGGTTTTAGTAATTGGTTATGA & $\begin{array}{l}\text { II } 66317-1166347 \\
\text { II } 90074-1190104\end{array}$ & 59 & $\mathrm{~T}$ \\
\hline IPpQTM2-R & CACGCTCTAGACTAATAATTTCTTCTGGTA & $\begin{array}{l}\text { II66433-II66404 } \\
1190190-1190161\end{array}$ & 61 & $\mathrm{~T}$ \\
\hline IPPQTM2-MGB & AAAAATTTCTGGGTTTGCTCAA & $\begin{array}{l}1166357-1166378 \\
1190114-1190135\end{array}$ & 53 & TP \\
\hline
\end{tabular}

a Based on nucleotide sequence NC_005364, the complete genome of M. mycoides subsp. mycoides SC type strain PGI [10]. The bgl gene spans the reverse of nt 954623-956059; the two copies of IPpQ in PGI span nt II65902-1167239 and nt II89659-1 I90996. Note that IppQ occurs only in one copy in all other M. mycoides subsp. mycoides SC strains (not shown).

b Obtained with the "Oligonucleotide Properties Calculator" at http://www.basic.northwestern.edu/biotools/oligocalc.html, using the nearest neighbor method and the parameters $300 \mathrm{nM}$ primer and $50 \mathrm{mM}$ salt $\left(\mathrm{Na}^{+}\right)$.

c P, amplification of bg/ by PCR; S, sequencing; T, TaqMan assay for quantitative detection; TP, TaqMan probe. 


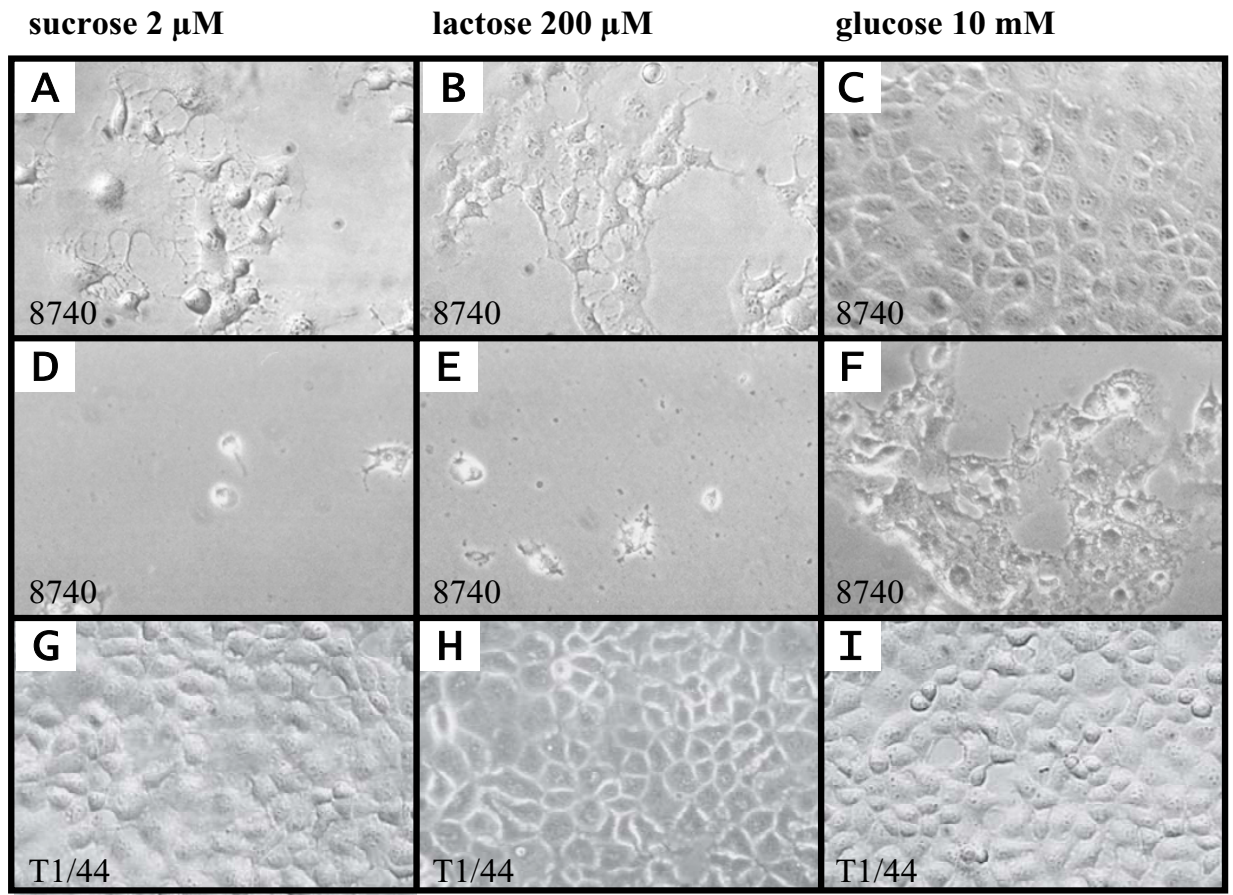

$4 \mathrm{~h}$

$24 \mathrm{~h}$

$24 \mathrm{~h}$

$24 \mathrm{~h}$

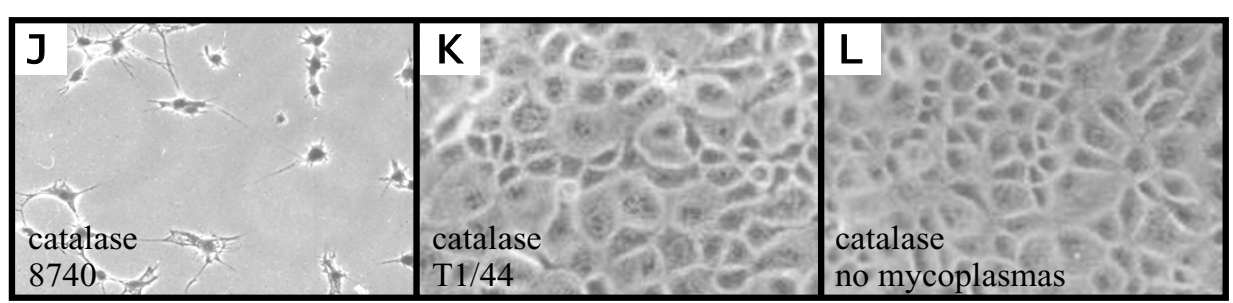

sucrose
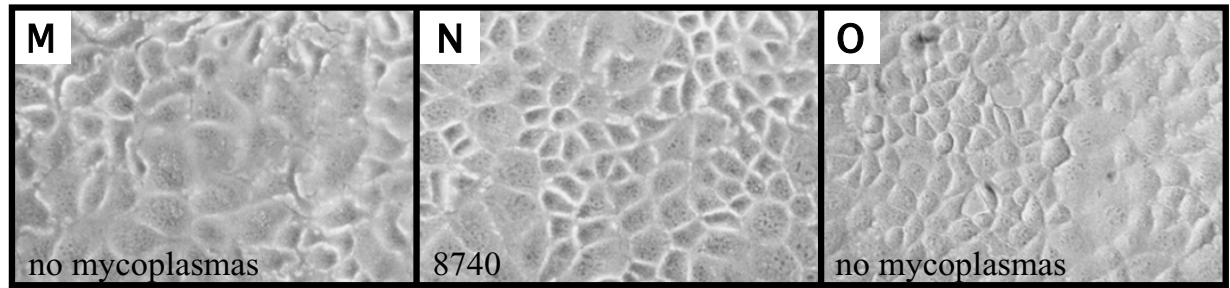

$24 \mathrm{~h}$

\section{Figure 2}

Effect of sugars on cytotoxicity of $\mathbf{M}$. mycoides subsp. mycoides SC on bovine lung cells in vitro. Representative photomicrographs $(320 \times)$ of EBL cell morphology upon mycoplasma infection in the presence of sugars. Pictures were taken after a $4 \mathrm{~h}$ incubation with the African field strain 8740 in the presence of sucrose $(2 \mu \mathrm{M}$, panel $\mathrm{A})$, lactose $(200 \mu \mathrm{M}$, panel $\mathrm{B})$ or the monosaccharide glucose ( $10 \mathrm{mM}$, panel $\mathrm{C}$ ) and again after $24 \mathrm{~h}$ (panels D-F). After $24 \mathrm{~h}$, pictures of EBL cell monolayers incubated with the less virulent vaccine strain TI/44 in the presence of these three sugars were also taken (panels G-I). Catalase $(160 \mathrm{U} / \mathrm{ml})$ was added to the EBL cells, which were then incubated for $24 \mathrm{~h}$ with strain 8740 and sucrose (panel J), or with strain TI/44 and sucrose (panel K). Controls performed to exclude eventual toxic effects of catalase alone (panel L), sugars alone (e.g., sucrose, panel $M$ ) or of strain 8740 without sugars (panel $N$ ) are also shown. Panel O shows EBL cells that were not treated at all. 
$\mu \mathrm{g} / \mathrm{ml}$ by strain 8740 , and $7.5-7.75 \mu \mathrm{g} / \mathrm{ml}$ by vaccine strain T1/44 after $1 \mathrm{~h}$. All $\mathrm{H}_{2} \mathrm{O}_{2}$ concentrations measured were retained up to $2 \mathrm{~h}$ and showed no significant differences between the two strains.

\section{Viability of M. mycoides subsp. mycoides SC upon incubation with different sugars and growth analysis of surviving cells}

Starvation in incubation buffer alone, or in incubation buffer supplemented with $5 \mathrm{mM}$ glucose or $5 \mu \mathrm{M}$ sucrose affected the viability of $M$. mycoides subsp. mycoides SC strains 8740 and T1/44. Over the first $4 \mathrm{~h}$ of starvation, there was an overall loss of $7-39 \%$ of viable mycoplasma cells. After $18 \mathrm{~h}$ of starvation, the number of CFU for strain $\mathrm{T} 1 / 44$ declined sharply to a rate of $<1 \%$ of the original in the three assays (loss of $>99 \%$ ), while that for strain 8740 was reduced to $<1 \%$ in incubation buffer alone and in the presence of glucose, and to approximately $12 \%$ in the presence of sucrose (Table 3 ).

The estimated quantities of mycoplasma cells of strains 8740 and T1/44 grown for 2 days after a preceding impregnation phase of $18 \mathrm{~h}$ with sucrose or glucose were determined in the TaqMan real-time PCR with primers and probe listed in Table 2 . The Ct values shown in Table 4 are mean values of two or more replicate experiments $(P$ $<0.0001$; ANOVA: single factor analysis). Results showed that pre-treatment with incubation buffer in the absence of sugars for $18 \mathrm{~h}$ completely blocked the growth of both strains. Also pre-incubation of the two strains of $M$. mycoides subsp. mycoides SC with $5 \mathrm{mM}$ glucose in incubation buffer affected dramatically their growth rate and the amounts of mycoplasmas grown in the 2-day culture were below $4 \%$ when compared to those of non-treated mycoplasmas (Table 4). Pre-incubation with $5 \mu \mathrm{M}$ sucrose blocked the subsequent growth of strain T1/44 ( $\approx 1 \%)$, while strain 8740 retained a growth of approximately $15 \%$ of the rate without treatment (Table 4 ).

\section{Discussion}

A single genetic difference between African field strains of M. mycoides subsp. mycoides SC and T1-derived vaccine strains was reported recently in the genomic region harbouring the genes frvA, suk and $b g l$ [35]. This genetic difference is an SNP in the $b g l$ gene coding for the 6phospho- $\beta$-glucosidase $(\mathrm{Bgl})$. Here we report the correlation of the two isoforms of Bgl to the cytotoxic potential of M. mycoides subsp. mycoides SC.

In cytotoxicity studies where we examined the effect of $M$. mycoides subsp. mycoides SC grown in the presence of certain mono- and disaccharides towards cultivated embryonic bovine lung (EBL) cells, the group of strains expressing the $\mathrm{Bgl}$ isoform $\mathrm{Val}_{204}$ showed high cytotoxicity in the presence of $\beta$-D-glucosides. This group contained principally highly virulent African field strains such as strains Afadé and 8740 [37-39]. In contrast, strains with the $\mathrm{Bgl}$ isoform $\mathrm{Ala}_{204}$ showed virtually no cytotoxicity in the presence of the two disaccharides sucrose or lactose. Most of the strains in this group are considered to be less virulent, in particular the vaccine strains T1/44 and T1/ Sr50 used in this study $[12,40]$. Other strains in this group are the type strain PG1 that is not considered to be virulent (probably due to a high number of in vitro passages [41]), the European strains from outbreaks of 1980-2000, which primarily caused epidemics with low mortality [42] and of which a characteristic strain was shown experimentally to be of low virulence $[37,38]$, and the Australian strains whose virulence in relation to the former strains has not been described. Other disaccharides such as the $\alpha$ -

Table 3: Viability of $M$. mycoides subsp. mycoides SC cell suspensions upon starvation at $37^{\circ} \mathrm{C}$ in medium-free buffers supplemented with $5 \mu$ sucrose or 5 mM glucose

\begin{tabular}{|c|c|c|c|}
\hline \multirow[t]{2}{*}{ incubation time $(\mathrm{h})$} & \multicolumn{3}{|c|}{ CFUa } \\
\hline & HEPES & glucose & sucrose \\
\hline \multicolumn{4}{|c|}{ strain 8740} \\
\hline 0 & $\approx 10^{7}$ & $\approx 10^{7}$ & $\approx 10^{7}$ \\
\hline 4 & $61 \times 10^{5}(61 \%)$ & $82 \times 10^{5}(82 \%)$ & $93 \times 10^{5}(93 \%)$ \\
\hline 18 & $165 \times 10^{2}(0.16 \%)$ & $21 \times 10^{3}(0.21 \%)$ & $123 \times 10^{4}(12.3 \%)$ \\
\hline \multicolumn{4}{|c|}{ strain $\mathrm{Tl} / 44$} \\
\hline 0 & $\approx 10^{7}$ & $\approx 10^{7}$ & $\approx 10^{7}$ \\
\hline 4 & $77 \times 10^{5}(77 \%)$ & $87 \times 10^{5}(87 \%)$ & $83 \times 10^{5}(83 \%)$ \\
\hline 18 & $131 \times 10^{2}(0.13 \%)$ & $35 \times 10^{3}(0.35 \%)$ & $104 \times 10^{2}(0.10 \%)$ \\
\hline
\end{tabular}

\footnotetext{
a For all assays, the original CFU (at time zero) was considered as being $\approx 10^{7}\left(10 \mu \mathrm{l}\right.$ of a suspension containing $\left.\approx 10^{9} \mathrm{CFU} / \mathrm{ml}\right)$. CFUs are reported as number of colonies formed in a specific sector of the plate $X$ dilution factor. Numbers in parentheses represent the percentages in relation to the initial $10^{7} \mathrm{CFU}$.
} 
Table 4: Estimated growth of $M$. mycoides subsp. mycoides SC after treatment with $5 \mu$ sucrose or 5 mM glucose

\begin{tabular}{|c|c|c|c|c|}
\hline Pre-treatment of $18 \mathrm{~h}^{\mathrm{a}}$ & $\mathrm{Ct}$ & Estimated quantity (geq) ${ }^{\mathrm{b}}$ & Culture titre (mycoplasmas $/ \mathrm{ml})^{\mathrm{c}}$ & Growth efficacy (\%) \\
\hline \multicolumn{5}{|c|}{ strain 8740} \\
\hline none & 18.26 & $6.94 \times 10^{6}$ & $2.77 \times 10^{9}$ & 100.00 \\
\hline HEPES & 25.50 & $6.12 \times 10^{4}$ & $2.45 \times 10^{7}$ & -0.20 \\
\hline glucose & 22.85 & $3.46 \times 10^{5}$ & $1.38 \times 10^{8}$ & 3.94 \\
\hline sucrose & 21.07 & $1.11 \times 10^{6}$ & $4.42 \times 10^{8}$ & 15.02 \\
\hline \multicolumn{5}{|c|}{ strain $\mathrm{Tl} / 44$} \\
\hline none & 18.13 & $7.55 \times 10^{6}$ & $3.02 \times 10^{9}$ & 100.00 \\
\hline HEPES & 24.85 & $9.35 \times 10^{4}$ & $3.74 \times 10^{7}$ & 0.25 \\
\hline glucose & 23.57 & $2.16 \times 10^{5}$ & $8.63 \times 10^{7}$ & 1.88 \\
\hline sucrose & 24.20 & $1.43 \times 10^{5}$ & $5.72 \times 10^{7}$ & 0.91 \\
\hline
\end{tabular}

\footnotetext{
a After pre-treatment with the indicated compound, mycoplasmas were grown for 2 days at $37^{\circ} \mathrm{C}$ in mycoplasma medium. Compounds: none, mycoplasmas were not subjected to any pre-treatment but were immediately diluted with mycoplasma medium for cultivation of 2 days at $37^{\circ} \mathrm{C}$; sucrose/glucose, mycoplasmas were pre-treated for $18 \mathrm{~h}$ at $37^{\circ} \mathrm{C}$ with sucrose or glucose in incubation buffer prior to cultivation for 2 days in mycoplasma medium; HEPES, mycoplasmas were pre-treated with incubation buffer alone.

${ }^{\mathrm{b}}$ As determined by the formula geq $=1.05 \times 10^{12} \times \mathrm{e}^{-0.65} \times \mathrm{Ct}$ generated by the TaqMan standard curve.

c The culture titre for each test was obtained by multiplying the corresponding geq (amount of total mycoplasmas in $2.5 \mu \mathrm{l}$ of lysate) by a factor of 400.

d Calculated by first subtracting the $3 \times 10^{7} \mathrm{CFU}$ of departure from each culture titre and considering then as $100 \%$ the resulting amount of nontreated mycoplasmas grown in 2-day cultures.
}

D-glucosides maltose and trehalose were not tested, as it has been shown that M. mycoides subsp. mycoides SC are unable to metabolize them [43-45]. Qualitative determination of pNPbG hydrolysis by $M$. mycoides subsp. mycoides SC grown on solid medium indicated that strains considered virulent and expressing the $\mathrm{Bgl}$ isoform $\mathrm{Val}_{204}$ have a reduced 6 -phospho- $\beta$-glucosidase activity. It is worthwhile noting at this point, that the pattern and rates of disaccharide utilization were similar among the $M$. mycoides subsp. mycoides SC strains tested and thus there were no differences in substrate uptake that could account for different rates of pNPbG hydrolysis, which could thus be appropriately referred to as $\mathrm{Bgl}$ activity. However, it has to be considered that the SNP was found in the bgl gene, while no genetic differences were found in the genes frvA and suk, but it is possible that differences in $f r v B$ or in the sugar hydrolase gene are also present and could account for different pNPbG hydrolysis patterns as well. Other sugar metabolism genes are likely to be involved in the flow of $\beta$-D-glucosides into glycolysis, thus contributing to the similar pattern of disaccharide utilization among strains. In this regard, there are a number of other PTS enzymes or sugar metabolism proteins that are annotated in the genome of M. mycoides subsp . mycoides SC [10] and which may also be involved in $\beta$-D-glucoside metabolism.

Glucosides like disaccharides are among the most important and most common carbon and energy sources for bacteria. Disaccharides are accumulated as phosphorylated derivatives by the translocation-phosphorylation mechanism PEP-PTS and are cleaved by intracellular sub- strate-specific phospho-glycosylhydrolases such as $\mathrm{Bgl}$ [36]. Specifically, Bgl hydrolyzes the $\beta$-glycosidic linkage between the anomeric carbon and glycosidic oxygen of intracellular phospho- $\beta$-D-glucosides. The residual monosaccharides obtained by this enzymatic reaction are then phosphorylated before being metabolized during glycolysis or undergo other metabolic reactions such as sugar oxidation. In mycoplasmas, oxidation of sugars together with oxidation of organic acids or glycerol lead to production of $\mathrm{H}_{2} \mathrm{O}_{2}$ [46]. Glycerol-dependent $\mathrm{H}_{2} \mathrm{O}_{2}$ production was shown to be a virulence determinant in $M$. mycoides subsp. mycoides SC and attenuated strains were found to have a defect in glycerol-related $\mathrm{H}_{2} \mathrm{O}_{2}$ generation $[31,32]$. In contrast, the amount of $\mathrm{H}_{2} \mathrm{O}_{2}$ produced by mycoplasmas grown in the presence of sugars is approximately 20 times less if compared to that produced in the presence of glycerol [47]. The low production of $\mathrm{H}_{2} \mathrm{O}_{2}$ by M. mycoides subsp. mycoides SC upon incubation with sugars was confirmed in our work and, moreover, in our cytotoxicity studies we could demonstrate that sugar-mediated $\mathrm{H}_{2} \mathrm{O}_{2}$ production by this mycoplasma does not contribute to induction of cell damage in the host, as addition of catalase, which behaves as a catalyst for the conversion of $\mathrm{H}_{2} \mathrm{O}_{2}$ into water and oxygen, could not block the cytotoxic effect.

Our study indicated that cytotoxicity of M. mycoides subsp. mycoides SC is related to defective $\mathrm{Bgl}$ activity. We thus assumed that $\beta$-D-glucosides could mediate in some extent repression of certain virulence factors of $M$. mycoides subsp. mycoides SC, as already reported for other 
pathogens $[48,49]$. This mechanism is known as carbon catabolite repression (CCR). In most bacteria, the enzymes involved in sugar transport and phosphorylation are known to play an essential role in signal generation leading through different transduction mechanisms to CCR that may mediate downregulation of virulence genes [50]. Viability tests and growth analysis of mycoplasma cells that have come through preceding impregnation with sugars in medium-free buffers indicated however that $\mathrm{Bgl}$ activity was rather involved in the control of growth of M. mycoides subsp. mycoides SC. In fact, the African field strains that possess the defective Bgl isoform $\mathrm{Val}_{204}$ were found to be more able than vaccine strains, which express the $\mathrm{Bgl}$ isoform $\mathrm{Ala}_{204}$, to preserve viable mycoplasma cells in the presence of $\beta$-D-glucosides such as sucrose or lactose, i.e., strains that seem to be particularly virulent are capable to subsist in some degree in environments that contain $\beta$-D-glucosides, while strains that have an attenuated virulence are not prone to $\beta$-D-glucosides and may succumb. Bacterial growth inhibition by elevated sugar metabolism was already described for Escherichia coli [51]. Two different mechanisms for this cessation of growth and substantial loss of viability were distinguished. One mechanism involved cell killing and the other mechanism resulted in growth inhibition without cell death. Cell killing was related to increased flux through glycolysis and consequent overproduction of the toxic metabolite methylglyoxal. Inhibition of growth resulted from excessive accumulation of organophosphates in the cell or depletion of inorganic phosphate pools [51]. It is possible that one or both of these "selfinflicted injury" mechanisms for growth inhibition also occurs in strains of M. mycoides subsp. mycoides SC considered of low virulence and possessing the active Bgl isoform $\mathrm{Ala}_{204}$ upon elevated utilization of $\beta$-D-glucosides. On the other hand, strains possessing the defective Bgl isoform $\mathrm{Val}_{204}$ do not metabolize $\beta$-D-glucosides in the same "self-inflicting" way and may rather use the latter in a different molecular mechanism of pathogenicity that enables them to exert cytotoxicity on host cells.

Almost no EBL cell damage was observed upon incubation with mycoplasmas in the presence of monosaccharides. Minor cell damage was observed only with strains 8740 or Afadé after a prolonged incubation of $24 \mathrm{~h}$ with glucose, fructose or galactose, while $\mathrm{T} 1 / 44$ was completely non-cytotoxic upon monosaccharide incubation. This indicated the presence of additional determinant(s) of cytotoxicity other than defective Bgl activity and glycerol metabolism in M. mycoides subsp. mycoides SC. A possible explanation why significant cytotoxicity in our experiments was only seen in the presence of some strains with sucrose and lactose, and not with monosaccharides, can reside in the fact that M. mycoides subsp. mycoides SC may be sensitive to high levels of monosaccharides. Note that the determined saturation constants $\left(K_{\mathrm{m}}\right)$ for glucose and fructose in M. mycoides subsp. mycoides SC are $<5 \mu \mathrm{M}$ $[44,52]$, while we have applied calculated physiological concentrations for monosaccharides which were significantly (up to $>3 \mathrm{log}$ ) higher than the $K_{\mathrm{m}}$ values. It is possible that such high carbohydrate concentrations may determine a high sugar metabolism rate and, consequently, a high production of toxic metabolites. The latter, in turn, may induce cessation of growth of all $M$. mycoides subsp. mycoides SC isolates, similarly to what observed upon starvation of less cytotoxic strains with $\beta$ D-glucosides.

As gene inactivation by homologous recombination [53] is currently impossible to achieve in M. mycoides subsp. mycoides SC (C. Janis \& A. Blanchard, personal communication), no bgl inactivation could be assessed in the vaccine strain $\mathrm{T} 1 / 44$ in order to directly verify if the difference in the $b g l$ gene is related to modulation of cytotoxicity of M. mycoides subsp. mycoides SC or not. However, there is evidence that the detected difference in the Bgl isoforms $\mathrm{Ala}_{204}$ and $\mathrm{Val}_{204}$ is close to (hence can influence) the catalytic site of the 6-phospho- $\beta$-glucosidase, as evidenced in an in silico three-dimensional (3D) localization of amino acid 204 of Bgl (see additional files 1 and 2). As no 3D structures are available for $\mathrm{Bgl}$ of $\mathrm{M}$. mycoides subsp. mycoides SC, comparison of the Bgl sequence from strain Afadé with available sequences from the NCBI site was performed with the Conserved Domain Database (CDD). Alignment with sequences belonging to the cluster of orthologous groups of proteins COG2723 (BglB: $\beta$-glucosidase/6-phospho- $\beta$-glucosidase/ $\beta$-galactosidase) and to the protein domain family pfam00232 (glyco_hydro_1: glycosyl hydrolase family 1) was obtained (see additional file 1). Comparison of Bgl with related proteins that have known 3D structures revealed homologies with the chain A sequences of the $\beta$-glycosidase from Sulfolobus solfataricus (1GOW_A) [54], the $\beta$ glucosidase from Zea mays (1HXJ_A) [55], and the 6phospho- $\beta$-galactosidase from Lactococcus lactis (1PBG_A) [56]. As 1PBG_A presented the highest homology with Bgl from M. mycoides subsp. mycoides SC among the three characterized proteins, the software Cn3D 4.1 from NCBI was used to visualize the 3D structure of 1PBG_A with the aim to envisage the structure of $\mathrm{Bgl}$ (see additional file 2). Protein 1PBG_A showed three Glu residues in the active site and a Val residue in its vicinity. These four amino acids are equivalent to the catalytic triad and the SNPrelated Val residue $\left(\mathrm{Val}_{204}\right)$ in the Bgl protein of African field strains of M. mycoides subsp. mycoides SC. Protein 1PBG_A is an active enzyme in $L$. lactis $[57,58]$ but we do not have any information as to if its $\mathrm{Val}_{185}$ is essential or not for enzymatic activity. It has to be noted at this point, that a transition between Ala and Val not involving the catalytic site has been already reported to be implicated in 
modulation of enzyme activities [59-61]. Such amino acid substitutions may modify the steric properties that are associated with the enzymatic activities by prompting conformational changes near the active site. These conformational changes may arise from the fact that Ala and Val have a different side-chain volume and therefore a transition Ala to Val can confer a different secondary structure to the enzyme $[62,63]$.

\section{Conclusion}

To cause disease or to be virulent, M.mycoides subsp. mycoides SC possesses multiple molecular mechanisms of pathogenicity [64]. These mechanisms permit mycoplasma to adhere to specific host tissue, to evade the host's immune defence, to enable persistence and dissemination in the infected animal, to exert a cytotoxic effect, and to cause inflammation and disease symptoms. The loss of any of these mechanisms can lead to attenuation or loss of virulence. Our observations of significant differences in cytotoxicity among $\mathrm{Bgl}$ variants of $\mathrm{M}$. mycoides subsp. mycoides SC grown in the presence of different sugars indicate that the $\beta$-D-glucoside metabolism is involved in control of pathogenicity of M. mycoides subsp. mycoides SC. This mechanism is independent of $\mathrm{H}_{2} \mathrm{O}_{2}$ production, in contrast to glycerol metabolism [31,32]. Rather, cytotoxicity observed in the presence of $\beta$-D-glucosides seems to be due to the effect of defective 6-phospho- $\beta$-glucosidase activity on the containment of cell death. At this point, it is important to know that lungs have an effective innate defence system to counteract the airborne bacteria that are constantly inhaled. These organisms land in the thin layer of the liquid that overlays the cells lining the inside of the lungs. The lung cells produce natural antibiotic substances, such as polypeptides and glycoproteins, and secrete them into the airway surface liquid where they kill the invading bacteria [65-67]. Also, degradation of the saccharide moiety of glycoproteins generates sugars [68], which, acting synergistically with other agents, may contribute to provide a defence barrier to colonization and infection in the host's lungs. As sugars are able to affect viability of those bacteria that are able to metabolize them in large amounts [51], a defective 6-phospho- $\beta$-glucosidase activity in strains harbouring the $\mathrm{Bgl}$ isoform $\mathrm{Val}_{204}$ can contribute indirectly to their higher virulence, due to the fact that they possess a sort of "resistance" to elevated levels of certain sugars and may use them as a supplement for cytotoxicity on host cells.

\section{Methods \\ Mycoplasma strains, growth conditions and DNA extraction}

Strains of M. mycoides subsp. mycoides SC used in this study are listed in Table 1. Mycoplasmas were grown in a standard mycoplasma medium (Axcell Biotechnologies, St. Genis l'Argentière, France) for 3 days at $37^{\circ} \mathrm{C}$ to a den- sity of $10^{8}-10^{9}$ cells $/ \mathrm{ml}$ or on solid mycoplasma agar medium (Axcell Biotechnologies). Growth and handling of live M. mycoides subsp. mycoides SC were performed in a biological safety laboratory fulfilling the BSL-3 containment safety standards. Lysis of mycoplasmas with GES buffer (5 M guanidium thiocyanate, $100 \mathrm{mM}$ EDTA, $0.5 \% N$-lauroylsarcosine) and extraction of genomic DNA were performed as previously described [69].

\section{Sequencing strategies}

To sequence the $b g l$ gene of the strains listed in Table 1, polymerase chain reaction (PCR) was first performed with a DNA thermal cycler Gene Amp 9600 (Applied Biosystems, Foster City, CA, USA) in a 50- $\mu$ l reaction mixture [50 $\mathrm{mM}$ Tris-HCl, $\mathrm{pH}$ 9.2, $1.75 \mathrm{mM} \mathrm{MgCl}_{2}, 16 \mathrm{mM}$ $\left(\mathrm{NH}_{4}\right)_{2} \mathrm{SO}_{4}, 350 \mu \mathrm{M}$ of each dNTP] that contained approximately $50 \mathrm{ng}$ of genomic template DNA, $300 \mathrm{nM}$ of oligonucleotide primers 4000bp_6L and 4000bp_2R (Table 2), and $1.75 \mathrm{U}$ of a mixture of Taq and Pwo DNA polymerases (Expand Long Template PCR System kit, Roche Diagnostics, Rotkreuz, Switzerland). The mixtures were subjected to 2 -min denaturation at $94{ }^{\circ} \mathrm{C}$ followed by 35 cycles of amplification with the parameters: $30 \mathrm{~s}$ at $94^{\circ} \mathrm{C}$, 30 s at $48^{\circ} \mathrm{C}$, and 3 min extension at $68^{\circ} \mathrm{C}$. Amplicons were purified with the High pure PCR product purification kit (Roche Diagnostics).

DNA sequencing of the purified amplicons was performed with a DNA Sequenator AB 3100 genetic analyzer and the Taq dye deoxy terminator cycle sequencing kit (Applied Biosystems) by primer walking using internal $b g l$ primers (Table 2). Assembling of DNA sequences and alignments of sequenced segments were done using the program Sequencher 4.6 (GeneCodes, Ann Arbor, MI, USA). Comparisons of DNA sequences and their deduced amino acid sequences with the EMBL/GenBank database were performed using the BLAST programs blastn, blastx and blastp [70].

\section{Mycoplasma preparation for the assays}

Mycoplasma cultures were grown to the exponential phase, determined by counting the number of colony forming units (CFU) on solid medium and by evaluating 3-(4,5-dimethyltiazol-2-yl)-2,5-diphenyl-tetrazolium bromide reduction rate as previously described [71]. After centrifuging the cultures at $36,000 \times g$ for $30 \mathrm{~min}$, pellets were resuspended in fresh medium to $50 \%$ of the initial volume. Aliquots of $5 \mathrm{ml}$ were stored at $-80^{\circ} \mathrm{C}$. The day before the assays, these cultures were thawed and incubated overnight at $37^{\circ} \mathrm{C}$. They were then centrifuged as stated above and the pellets were washed once and resuspended with the aid of a 27-gauge needle in the appropriate buffer or medium (depending on the assay). The number of CFU was counted and adjusted to the desired densities (see below). 


\section{Carbohydrate utilization tests}

Conventional biochemical tests were performed to measure the utilization of glucose, fructose, galactose, sucrose and lactose in a serum-free medium by M. mycoides subsp. mycoides SC strains L2, Afadé, 8740, T1/44 and Gladysdale (Table 1). Sera or heat-inactivated sera were omitted to avoid possible saccharolytic activity by enzymes that can give fallacious results in sugar fermentation tests. The sterile laboratory-prepared basal medium containing bovine serum albumin, lipids, glycerol and penicillin $G$ was prepared as described [43]. The basal medium was supplemented with bromothymol blue as indicator, which detects the presence of $\mathrm{CO}_{2}$ in the media. Either filter-sterilized carbohydrate solutions were added to the sterile basal medium ( $\mathrm{pH} 7.6$ ) to give final concentrations of $0.1 \%$. The biochemical tests were inoculated with approximately $10^{8} \mathrm{CFU} / \mathrm{ml}$ M. mycoides subsp. mycoides SC from the pellet preparations described above, incubated at $37^{\circ} \mathrm{C}$ in ambient air for 6 days and examined daily for reactions. Media turning yellow in colour indicated a positive carbohydrate utilization test.

\section{Bovine lung cell cultivation}

Embryonic bovine lung (EBL) cells (ACC192; DSMZ, Braunschweig, Germany) were cultivated in Eagle's Minimum Essential Medium (MEM; Gibco Life Technologies, Gaithersburg, MD, USA) containing $2 \mathrm{mM}$ L-glutamine supplemented with $4 \%$ foetal bovine serum (Gibco Life Technologies) and $50 \mu \mathrm{g} / \mathrm{ml}$ gentamicin. This medium was previously filtered by $0.1 \mu \mathrm{m}$ filters (PALL Gelman Laboratory, Ann Arbor, MI, USA). To obtain a confluent monolayer, $5 \times 10^{4}$ freshly trypsinized cells were inoculated into each cavity of 24-well tissue culture plates (NUNC Brand Products, Rochester, NY, USA) and incubated for approximately $48 \mathrm{~h}$ at $37^{\circ} \mathrm{C}$ in an atmosphere of $5 \% \mathrm{CO}_{2}$. The MycoFluor KIT (Molecular Probes, Eugene, OR, USA) was used as described by the manufacturer to ensure that cell cultures were free of mycoplasma contamination.

\section{Effect of M. mycoides subsp. mycoides SC on EBL cells in the presence of different sugars}

To study the cellular effect of mycoplasma metabolism in the presence of different sugars, pellets of $M$. mycoides subsp. mycoides SC strains Afadé, 8740, T1/44, B345/93 and L2 (Table 1) were resuspended in MEM (without supplements and gentamicin) at a density of approximately 5 $\times 10^{8} \mathrm{CFU} / \mathrm{ml}$ and then used to infect EBL cells.

Different final concentrations of the disaccharides sucrose $(2,5$ and $10 \mu \mathrm{M})$ and lactose $(50,100$ and $200 \mu \mathrm{M})$, and of the monosaccharides glucose $(2,5$ and $10 \mathrm{mM})$, fructose $(50,100$ and $200 \mu \mathrm{M})$ and galactose (50, 100 and $200 \mu \mathrm{M}$ ) were used. The sugar concentrations corresponded to the physiological levels in bovine serum and were computed as follows: the lactose concentration was derived from previous work $[72,73]$ and ranges from 40$60 \mu \mathrm{M}$ up to $230 \mu \mathrm{M}$ in lactating cows; the concentration applied for glucose was derived from physiological levels measured in adult cattle (2.5-4.2 $\mathrm{mM}$, up to $8.9 \mathrm{mM}$ in veal calves; J. Blum, personal communication). As no data were available for concentrations of the other three sugars in cattle, we have considered as references their standard values in human blood (approximately $2 \mu \mathrm{M}$ sucrose, 30$50 \mu \mathrm{M}$ fructose and 50-100 $\mu \mathrm{M}$ galactose). Prior to infection of EBL cells, equal volumes $(250 \mu \mathrm{l})$ of mycoplasma suspensions $\left(\approx 1.25 \times 10^{8} \mathrm{CFU}\right)$ and sugars $(2 \times$ final concentration) were incubated for $20 \mathrm{~min}$ at $37^{\circ} \mathrm{C}$. Cell monolayers $\left(\approx 2 \times 10^{5}\right.$ cells $)$ were washed twice with Hank's Balanced Salt Solutions (Gibco Life Technologies) and then incubated with the inocula $(500 \mu \mathrm{l})$ for $24 \mathrm{~h}$. The EBL cells were thus infected at a multiplicity of infection (MOI) of 550-700 mycoplasmas per cell. In control experiments, $160 \mathrm{U} / \mathrm{ml}$ catalase (Sigma-Aldrich Chemie $\mathrm{GmbH}$, Buchs, Switzerland) was added to the cell monolayers prior to addition of the 500- $\mu$ l inocula in order to block the effect of $\mathrm{H}_{2} \mathrm{O}_{2}$ produced by mycoplasmas. Other controls consisted of cell monolayers inoculated with one of the following: i) MEM; ii) mycoplasmas; iii) sugars; and iv) catalase. EBL cell morphology was monitored by phase contrast every hour for 8 hours and at $24 \mathrm{~h}$ using a Leica DMIL microscope. Each assay was performed in triplicate.

\section{Bgl activity assay}

6-Phospho- $\beta$-glucosidase activity was determined qualitatively by measuring the hydrolysis of the chromogenic substrate $p$-nitrophenyl- $\beta$-D-glucopyranoside (pNPbG, Merck KGaA, Darmstadt, Germany) by intact mycoplasmas as already described for a similar substrate [45]. This is actually a coupled assay because degradation of $\beta$-glucosides by M. mycoides subsp. mycoides SC occurs by phosphorylation of the sugar during transport followed by hydrolysis of the glucosidic bond by the cytoplasmic Bgl to release $p$-nitrophenol [48].

Mycoplasma pellets from preparations described above were resuspended at a density of approximately $10^{8} \mathrm{CFU} /$ $\mathrm{ml}$ in fresh standard mycoplasma medium and aliquots of $5 \mu \mathrm{l}$ of 10 -fold dilutions ( 6 log units, from non-diluted to $10^{-5}$ ) were spotted on solid mycoplasma agar medium. $M$. mycoides subsp. mycoides SC were grown for 3 days at $37^{\circ} \mathrm{C}$ and then colonies were flooded with $600 \mu \mathrm{l}$ of $2 \mathrm{mM}$ pNPbG dissolved in incubation buffer (67.6 mM HEPES, pH7.3, $140 \mathrm{mM} \mathrm{NaCl}, 7 \mathrm{mM} \mathrm{MgCl}_{2}$ ). Incubation was continued for another $3 \mathrm{~h}$ at $37^{\circ} \mathrm{C}$. The reaction was blocked by adding $600 \mu \mathrm{l}$ of $500 \mathrm{mM} \mathrm{Na} \mathrm{CO}_{3}$; this stopped the hydrolysis reaction and enhanced the yellow coloration of colonies. Colony coloration was examined using a NIKON SMZ 1500 with $40 \times$ and $100 \times$ final magnifications. 


\section{Quantification of $\mathrm{H}_{2} \mathrm{O}_{2}$ production}

To measure $\mathrm{H}_{2} \mathrm{O}_{2}$ production, pellets of strains 8740 and T1/44 of M. mycoides subsp. mycoides SC (Table 1) resuspended at a density of approximately $10^{9} \mathrm{CFU} / \mathrm{ml}$ in prewarmed incubation buffer were incubated at $37^{\circ} \mathrm{C}$ for $1 \mathrm{~h}$. To induce $\mathrm{H}_{2} \mathrm{O}_{2}$ production, final concentrations of the disaccharides sucrose $(5 \mu \mathrm{M})$ and lactose $(100 \mu \mathrm{M})$ and of the monosaccharides glucose $(5 \mathrm{mM})$, fructose $(50 \mu \mathrm{M})$ and galactose $(100 \mu \mathrm{M})$ were added to the mycoplasma suspensions. The production of $\mathrm{H}_{2} \mathrm{O}_{2}$ was measured with the peroxide test (Merck KGaA) as previously described $[31,32]$ at time zero and after 1 - and 2-h incubation at $37^{\circ} \mathrm{C}$ in the presence of sugars. Each assay was performed in duplicate. The samples were then subjected to the mycoplasma viability and growth assay (see below). As a control for induction of $\mathrm{H}_{2} \mathrm{O}_{2}$ production, the two mycoplasmas were incubated with $100 \mu \mathrm{M}$ final concentration of glycerol.

\section{Viability measurement and growth analysis of surviving cells}

Viability measurement of strains 8740 and T1/44 upon 2$\mathrm{h}$ treatment with incubation buffer alone, with $5 \mu \mathrm{M}$ sucrose or with $5 \mathrm{mM}$ glucose was performed by counting the CFU formed on solid medium after another $2 \mathrm{~h}$ (totally $4 \mathrm{~h}$ incubation) and another $16 \mathrm{~h}$ (totally $18 \mathrm{~h}$ ) incubations at $37^{\circ} \mathrm{C}$ of the above $\mathrm{H}_{2} \mathrm{O}_{2}$ quantification assays. Aliquots of $10 \mu \mathrm{l}$ of 10 -fold serial dilutions were streaked with sterile loops on the solid medium in specific sectors of the plates, which were labelled with the corresponding dilution factors.

For measuring mycoplasma growth after pre-treatment with $5 \mu \mathrm{M}$ sucrose or $5 \mathrm{mM}$ glucose, we took $30-\mu \mathrm{l}$ aliquots from the above $\mathrm{H}_{2} \mathrm{O}_{2}$ quantification assay - originally containing approximately $3 \times 10^{7} \mathrm{CFU}$ of strains 8740 and $\mathrm{T} 1 / 44$ incubated with the corresponding sugars - and kept them at $37^{\circ} \mathrm{C}$ for another $16 \mathrm{~h}$ (totally $18 \mathrm{~h}$ incubation). As controls, $30 \mu$ of cells in incubation buffer for the two mycoplasmas $\left(\approx 3 \times 10^{7} \mathrm{CFU}\right)$ were kept at $37^{\circ} \mathrm{C}$ for $18 \mathrm{~h}$ in the absence of sugars. Cells were resuspended in $1 \mathrm{ml}$ of fresh standard mycoplasma medium and incubation at $37^{\circ} \mathrm{C}$ was continued for another 2 days. Other controls consisted of $60 \mu$ from 3-day-old cultures $\left(\approx 3 \times 10^{7} \mathrm{CFU}\right)$ that were not pre-warmed with incubation buffer but were immediately diluted with $1 \mathrm{ml}$ of fresh mycoplasma medium and then grown for 2 days. Mycoplasmas were then harvested by centrifugation at $8,000 \times$ $\mathrm{g}$ for $10 \mathrm{~min}$, washed and resuspended in $1 \mathrm{ml}$ sterile purified water, and boiled for $10 \mathrm{~min}$. These lysates were finally used to quantitatively evaluate the amount of mycoplasmas by TaqMan real-time PCR, where a timedependent signal increase was taken as a measure for growth efficacy of the mycoplasmas, revealing their viabil- ity. Reactions were performed using $2.5 \mu \mathrm{l}$ of each lysate, a $900 \mathrm{nM}$ concentration of each TaqMan primer (Table 2) and $300 \mathrm{nM}$ TaqMan probe (Table 2 ) in a $25-\mu$ l volume. Primers and probe specific to the lipoprotein gene $l p p Q$ of M. mycoides subsp. mycoides SC were designed using the Primer Express software (Applied Biosystems). 6FAM reporter dye and MGB quencher were affixed on the 5 ' and 3 ' ends of the probe, respectively. PCR reactions were run on an ABI 7500 instrument (Applied Biosystems) using the following cycling parameters: after one step at $50^{\circ} \mathrm{C}$ for $2 \mathrm{~min}$ and at $95^{\circ} \mathrm{C}$ for $10 \mathrm{~min}, 40$ cycles of denaturation at $95^{\circ} \mathrm{C}$ for $15 \mathrm{~s}$ and extension at $60^{\circ} \mathrm{C}$ for $1 \mathrm{~min}$ were performed. Real-time fluorescence measurements were taken and the cycle number at which the fluorescent signal crossed the threshold for each sample was recorded (Ct value). Each assay was repeated at least twice.

A standard curve was produced by analyzing 10-fold dilutions of the $l p p Q$-containing plasmid pJFFLP4811 [74] containing 0.7 to $7 \times 10^{10}$ genome equivalents (geq) in the TaqMan assay three times. It was linear over a range of $8 \log$ units, with amounts ranging from 7 to $7 \times 10^{7}$ geq in $2.5 \mu \mathrm{l}$ of analyzed samples, showing a correlation coefficient of $0.9987\left(r^{2}=0.9975\right)$. The estimated quantities of mycoplasma cells were determined using the formula geq $=1.05 \times 10^{12} \times \mathrm{e}^{-0.65 \times \mathrm{Ct}}$, generated by the linear regression of standard curve [Ct values vs. $\left.\log _{10}(\mathrm{geq})\right]$.

\section{Nucleotide sequence accession numbers}

The EMBL/GenBank accession numbers for the nucleotide sequences of the $b g l$ genes from seven of the ten $M$. mycoides subsp. mycoides SC strains used in this study (Table 1) have been deposited under accession numbers AM114901-

\section{Authors' contributions}

EMV, MHF and JF participated in the discussions on the study design. EMV, IC and MHF participated in analysis and interpretation of the data. EMV and DFB performed sequence analysis, quantification of $\mathrm{H}_{2} \mathrm{O}_{2}$ production and viability measurement by TaqMan. IC and MHF carried out the experiments with EBL cells. EMV, MHF and JF participated in the writing of the manuscript. EMV was the principal author of the manuscript. All authors read and approved the final manuscript. 


\section{Additional material}

\author{
Additional file 1 \\ Alignment of the Bgl amino acid sequence with those of related pro- \\ teins. The Bgl sequence from strain Afadé was aligned with the protein \\ sequences COG2723, pfam00232,1PBG_A, 1HXJ_A and 1GOW_A \\ using the program DIALIGN 2, and the alignment was elaborated with \\ Boxshade 3.21. The sequences for COG2723 (from Enterococcus fae- \\ cium) and pfam00232 (from Streptococcus pneumoniae) were \\ obtained with blastp and showed very high similarities with the Bgl \\ sequence from $\mathrm{M}$. mycoides subsp. mycoides SC. Black backgrounds \\ indicate identical amino acids and grey backgrounds indicate similar res- \\ idues. Asterisks (*) indicate the three Glu residues of the catalytic site and \\ the circle (o) indicates the amino acid 204 in the Bgl sequence from $\mathrm{M}$. \\ mycoides subsp. mycoides SC. \\ Click here for file \\ [http://www.biomedcentral.com/content/supplementary/1471- \\ 2180-7-31-S1.pdf]

\section{Additional file 2} \\ Three-dimensional model showing the secondary structures in the \\ vicinity of the active site of 1PBG_A. The "worm" model was obtained \\ with the program Cn3D 4.1. The residues $\mathrm{Glu}_{160} \mathrm{Glu}_{320}$ and $\mathrm{Gl} \mathrm{u}_{375}$ that \\ comprise the catalytic site are shown in yellow. The Val ${ }_{185}$ (corresponding \\ to $\mathrm{Val}_{204}$ in the Bgl of M. mycoides subsp. mycoides SC strain Afadé) is \\ shown in green. All other residues are shown in pink. Note that Glu 320 \\ was not displayed by Cn3D 4.1, as Bgl amino acids 315-324 do not have \\ a well-defined secondary structure, therefore its approximate location was \\ introduced manually. \\ Click here for file \\ [http://www.biomedcentral.com/content/supplementary/1471- \\ 2180-7-31-S2.pdf]
}

\section{Acknowledgements}

We are grateful to A. Blanchard and C. Janis (INRA, Université Victor Segalen Bordeaux 2, Villenave d'Ornon, France), and to J. Blum (Institute of Animal Genetics, Nutrition and Housing, University of Bern, Bern, Switzerland) for helpful contribution. This study was initially financed by the Swiss Ministry of Education and Science grant No. BBW99.0849 as part of the EU $5^{\text {th }}$ Framework programme INCO, contract No. ICA4-CT-2000-300 I5, and is currently supported by grant no. 075804 "A genomics approach to understanding the immunopathology of contagious bovine pleuropneumonia (CBPP): improvement of current live vaccines and the development of next generation vaccines" of the Wellcome Trust, London, UK.

\section{References}

I. Su CJ, Tryon VV, Baseman JB: Cloning and sequence analysis of cytadhesin PI gene from Mycoplasma pneumoniae. Infect Immun 1987, 55:3023-3029.

2. Dallo SF, Chavoya A, Baseman JB: Characterization of the gene for a 30-kilodalton adhesion-related protein of Mycoplasma pneumoniae. Infect Immun 1990, 58:4I63-4I65.

3. Dallo SF, Lazzell AL, Chavoya A, Reddy SP, Baseman JB: Biofunctional domains of the Mycoplasma pneumoniae P30 adhesin. Infect Immun 1996, 64:2595-260I.

4. Washburn LR, Weaver KE, Weaver EJ, Donelan W, Al-Sheboul S: Molecular characterization of Mycoplasma arthritidis variable surface protein MAA2. Infect Immun 1998, 66:2576-2586.

5. Chambaud I, Heilig R, Ferris S, Barbe V, Samson D, Galisson F, Moszer I, Dybvig K, Wróblewski H, Viari A, Rocha EPC, Blanchard A: The complete genome sequence of the murine respiratory path- ogen Mycoplasma pulmonis. Nucleic Acids Res 200I, 29:2।45-2।53.

6. Papazisi L, Gorton TS, Kutish G, Markham PF, Browning GF, Nguyen DK, Swartzell S, Madan A, Mahairas G, Geary S): The complete genome sequence of the avian pathogen Mycoplasma gallisepticum strain R(low). Microbiology 2003, 149:2307-2316.

7. Minion FC, Lefkowitz EJ, Madsen ML, Cleary BJ, Swartzell SM, Mahairas GG: The genome sequence of Mycoplasma hyopneumoniae strain 232 , the agent of swine mycoplasmosis. J Bacteriol 2004, 186:7| 23-7| 33 .

8. Hudson P, Gorton TS, Papazisi L, Cecchini K, Jr FS, Geary SJ: Identification of a virulence-associated determinant, dihydrolipoamide dehydrogenase (Ipd), in Mycoplasma gallisepticum through in vivo screening of transposon mutants. Infect Immun 2006, 74:93I-939.

9. Kannan TR, Baseman JB: ADP-ribosylating and vacuolating cytotoxin of Mycoplasma pneumoniae represents unique virulence determinant among bacterial pathogens. Proc Natl Acad Sci USA 2006, 103:6724-6729.

10. Westberg J, Persson A, Holmberg A, Goesmann A, Lundeberg J, Johansson KE, Pettersson B, Uhlen M: The genome sequence of Mycoplasma mycoides subsp. mycoides SC type strain PGIT, the causative agent of contagious bovine pleuropneumonia (CBPP). Genome Res 2004, I 4:22I-227.

11. Windsor RS: The eradication of contagious bovine pleuropneumonia from south western Africa. A plan for action. Ann $N$ Y Acad Sci 2000, 91 6:326-332.

12. Egwu GO, Nicholas RAJ, Ameh JA, Bashiruddin JB: Contagious bovine pleuropneumonia: an update. Vet Bull 1996, 66:875-888.

13. Plackett $P$, Buttery $\mathrm{SH}$ : A galactofuranose disaccharide from the galactan of Mycoplasma mycoides. Biochem J 1964, 90:20I-205.

14. Hudson JR, Buttery S, Cottew GS: Investigations into the influence of the galactan of Mycoplasma mycoides on experimental infection with that organism. I Pathol Bact 1967, 94:257-273.

15. Buttery SH, Lloyd LC, Titchen DA: Acute respiratory, circulatory and pathological changes in the calf after intravenous injections of the galactan from Mycoplasma mycoides subsp. mycoides. J Med Microbiol 1976, 9:379-39I.

16. March JB, Jones GE, Hitchen P, Morris HR, Dell A: Analysis of the capsular polysaccharide of Mycoplasma mycoides subsp. mycoides SC, the causal agent of CBPP: purification, composition and its role in infection and immunity. In Mycoplasmas of ruminants: pathogenicity, diagnostics, epidemiology and molecular genetics - Vol. 3 Edited by: Stipkovits L, Rosengarten R and Frey J. Brussels, European Communities; 1999:69-72.

17. March JB, Brodlie M: Comparison of the virulence of European and African isolates of Mycoplasma mycoides subspecies mycoides small colony type. Vet Rec 2000, 147:20-2I.

18. Herbelin A, Ruuth E, Delorme D, Michel-Herbelin C, Praz F: Mycoplasmaarginini TUH- 44 membrane lipoproteins induce production of interleukin- $I$, interleukin-6, and tumor necrosis factor alpha by human monocytes. Infect Immun 1994, 62:4690-4694.

19. Mühlradt PF, Frisch M: Purification and partial biochemical characterization of a Mycoplasmafermentans-derived substance that activates macrophages to release nitric oxide, tumor necrosis factor and interleukin-6. Infect Immun 1994, 62:380I-3807.

20. Brenner C, Wroblewski H, Le Henaff M, Montagnier L, Blanchard A Spiralin, a mycoplasmal membrane lipoprotein, induces $T$ cell-independent $B$-cell blastogenesis and secretion of proinflammatory cytokines. Infect Immun 1997, 65:4322-4329.

21. Calcutt MJ, Kim MF, Karpas AB, P.F. M, Wise KS: Differential posttranslational processing confers intraspecies variation of a major surface lipoprotein and a macrophage-activating lipopeptide of Mycoplasma fermentans. Infect Immun 1999, 67:760-771.

22. Marie C, Roman-Roman S, Rawadi G: Involvment of mitogenactivated protein kinase pathways in interleukin-8 production by human monocytes and polymorphonuclear cells stimulated with lipopolysaccharide or Mycoplasma fermentans membrane lipoproteins. Infect Immun 1999, 67:688-693.

23. Razin S, Yogev D, Naot Y: Molecular biology and pathogenicity of mycoplasmas. Microbiol Mol Biol Rev 1998, 62:1094-II56.

24. Peterson SN, Bailey CC, Jensen JS, Borre MB, King ES, Bott KF, Hutchison CA: Characterization of repetitive DNA in the Myc- 
oplasma genitalium genome: possible role in the generation of antigenic variation. Proc Natl Acad Sci USA 1995, 92: I I829-I I833.

25. Sachse K, Helbig JH, Lysnyansky I, Grajetzki C, Muller W, Jacobs E, Yogev D: Epitope mapping of immunogenic and adhesive structures in repetitive domains of Mycoplasma bovis variable surface lipoproteins. Infect Immun 2000, 68:680-687.

26. Persson A, Jacobsson K, Frykberg L, Johansson KE, Poumarat F: Variable surface protein $\mathrm{Vmm}$ of Mycoplasma mycoides subsp. mycoides small colony type. J Bacteriol 2002, I 84:37I2-3722.

27. Dedieu L, Chapey E, Balcer-Rodrigues V: Mycoplasma mycoides ssp. mycoides biotype small colony-secreted components induce apoptotic cell death in bovine leucocytes. Scand J Immunol 2005, 62:528-538.

28. Wadher BJ, Henderson CL, Miles RJ, Varsani H: A mutant of Mycoplasma mycoides subsp. mycoides lacking the H2O2-producing enzyme L-a-glycerophosphate oxidase. FEMS Microbiol Lett 1990, 72:127-130.

29. Houshaymi BM, Miles RJ, Nicholas RA: Oxidation of glycerol differentiates African from European isolates of Mycoplasma mycoides subspecies mycoides SC (small colony). Vet Rec 1997, I40: 182-183.

30. Rice P, Houshaymi BM, Abu-Groun EA, Nicholas RA, Miles RJ: Rapid screening of $\mathrm{H} 2 \mathrm{O} 2$ production by Mycoplasma mycoides and differentiation of European subsp. mycoides SC (small colony) isolates. Vet Microbiol 200I, 78:343-35I.

31. Vilei EM, Frey J: Genetic and biochemical characterization of glycerol uptake in Mycoplasma mycoides subsp. mycoides SC: its impact on $\mathbf{H 2 O 2}$ production and virulence. Clin Diagn Lab Immunol 200I, 8:85-92.

32. Pilo P, Vilei EM, Peterhans E, Bonvin-Klotz L, Stoffel MH, Dobbelaere $D$, Frey J: A metabolic enzyme as a primary virulence factor of Mycoplasma mycoides subsp. mycoides Small Colony. J Bacteriol 2005, I 87:6824-683I.

33. Vilei EM, Abdo EM, Nicolet J, Botelho A, Gonçalves R, Frey J: Genomic and antigenic differences between the European and African/Australian clusters of Mycoplasma mycoides subsp. mycoides SC. Microbiology 2000, I 46:477-486.

34. Djordjevic SP, Vilei EM, Frey J: Characterization of a chromosomal region of Mycoplasma sp. bovine group 7 strain PG50 encoding a glycerol transport locus (gtsABC). Microbiology 2003, I49: 195-204.

35. Vilei EM, Frey J: Differential clustering of Mycoplasma mycoides subsp. mycoides SC strains by PCR-REA of the bgl locus. Vet Microbiol 2004, 100:283-288.

36. Thompson J, Robrish SA, Bouma CL, Freedberg DI, Folk JE: Phospho-b-glucosidase from Fusobacterium mortiferum: purification, cloning, and inactivation by 6-phosphoglucono-deltalactone. J Bacteriol 1997, I 79:| 636-1645.

37. Pilloud T: Etude sur la reproduction expérimentale de la péripneumonie contagieuse bovine. In $\mathrm{PhD}$ thesis University of Bern, Institute of Veterinary Bacteriology; 1996.

38. Abdo EM, Nicolet J, Miserez R, Gonçalves R, Regalla J, Griot C, Bensaide $A$, Krampe $M$, Frey J: Humoral and bronchial immune responses in cattle experimentally infected with Mycoplasmamycoides subsp. mycoides small colony type. Vet Microbiol 1998, 59:109-122.

39. Lorenzon S, Arzul I, Peyraud A, Hendrikx P, Thiaucourt F: Molecular epidemiology of contagious bovine pleuropneumonia by multilocus sequence analysis of Mycoplasma mycoides subspecies mycoides biotype SC strains. Vet Microbiol 2003, 93:319-333.

40. Thiaucourt F, Lorenzon S, David A, Tulasne JJ, Domenech J: Vaccination against contagious bovine pleuropneumonia and the use of molecular tools in epidemiology. Ann N Y Acad Sci 1998, 849:|46-|5|.

41. Edward DG, Freundt EA: Type strains of species of the order Mycoplasmatales, including designation of neotypes for Mycoplasma mycoides subsp. mycoides, Mycoplasma agalactiae subsp. agalactiae and Mycoplasma arthritidis. Int J Syst Bacteriol 1973, 23:55-61.

42. Nicholas RAJ, Santini FG, Clark KM, Palmer NMA, DeSantis P Bashiruddin JB: A comparison of serological tests and gross lung pathology for detecting contagious bovine pleuropneumonia in two groups of Italian cattle. Vet $\operatorname{Rec} 1$ 1996, 139:89-93.
43. Miles RJ, Lee DH: Carbohydrate utilisation by Mycoplasma mycoides var mycoides strain $\mathrm{TI}$ in a medium without serum. Microbios Lett 1983, 24: I33.

44. Abu-Groun EA, Taylor RR, Varsani H, Wadher BJ, Leach RH, Miles R Biochemical diversity within the 'Mycoplasma mycoides' cluster. Microbiology 1994, I 40:2033-2042.

45. Rice P, Houshaymi BM, Nicholas RAJ, Miles RJ: A rapid biochemica test to aid identification of Mycoplasma mycoides subsp. mycoides small colony (SC) strains. Lett Appl Microbiol 2000, 30:70-74.

46. Miles RJ: Catabolism in mollicutes. I Gen Microbiol 1992, I38:1773-1783.

47. Miles RJ, Taylor RR, Varsani $\mathrm{H}$ : Oxygen uptake and $\mathbf{H 2 O 2}$ production by fermentative Mycoplasma spp. J Med Microbiol 1991, 34:219-223.

48. Kerppola TK, Serwold-Davis T, Gross DC, Kahn ML: Effect of increased b-glucosidase activity on virulence of Erwinia amylovora. Appl Environ Microbiol I987, 53:677-682.

49. Brehm K, Ripio MT, Kreft J, Vazquez-Boland JA: The bvr locus of Listeria monocytogenes mediates virulence gene repression by b-glucosides. J Bacteriol 1999, I 81:5024-5032.

50. Stulke J, Hillen W: Carbon catabolite repression in bacteria. Curr Opin Microbiol 1999, 2:195-201.

51. Kadner RJ, Murphy GP, Stephens CM: Two mechanisms for growth inhibition by elevated transport of sugar phosphates in Escherichia coli. J Gen Microbiol 1992, I38:2007-20I4.

52. Miles RJ, Beezer AE, Lee DH: Kinetics of utilization of organic substrates by Mycoplasma mycoides subsp. mycoides in a salts solution: a flow-microcalorimetric study. J Gen Microbiol | 985 , I 3 | : | 845- | 852.

53. Janis C, Lartigue C, Frey J, Wroblewski H, Thiaucourt F, Blanchard A Sirand-Pugnet $P$ : Versatile use of oriC plasmids for functional genomics of Mycoplasma capricolum subsp. capricolum. Appl Environ Microbiol 2005, 7I:2888-2893.

54. Pearl LH, Hemmings AM, Nucci R, Rossi M: Crystallization and preliminary $X$-ray analysis of the $b$-galactosidase from the extreme thermophilic archaebacterium Sulfolobus solfataricus. J Mol Biol 1993, 229:56I-563.

55. Vevodova J, Marek J, Zouhar J, Brzobohaty B, Su XD: Purification, crystallization and preliminary $X$-ray analysis of a maize cytokinin glucoside specific b-glucosidase. Acta Crystallogr D Biol Crystallogr 200।, 57:|40-|42.

56. Wiesmann C, Beste G, Hengstenberg W, Schulz GE: The threedimensional structure of 6-phospho-b-galactosidase from Lactococcus lactis. Structure 1995, 3:96|-968.

57. Wiesmann C, Hengstenberg W, Schulz GE: Crystal structures and mechanism of 6-phospho-b-galactosidase from Lactococcus lactis. I Mol Biol 1997, 269:85 I-860.

58. Schulte $D$, Hengstenberg $W$ : Engineering the active center of the 6-phospho-b-galactosidase from Lactococcus lactis. Protein Eng 2000, 13:515-518.

59. Goswitz VC, Brooker RJ: Isolation of lactose permease mutants which recognize arabinose. Membr Biochem 1993, 10:61-70.

60. Kirchberger J, Edelmann A, Kopperschlager G, Heinisch J): A single point mutation leads to an instability of the hetero-octameric structure of yeast phosphofructokinase. Biochem J 1999. 34|:|5-23.

61. Zhang Y, Wang PG, Brew K: Specificity and mechanism of metal ion activation in UDP-galactose:b-galactoside-a- I,3-galactosyltransferase. J Biol Chem 200I, 276: I I567-II 574.

62. Deber CM, Khan AR, Li Z, Joensson C, Glibowicka M, Wang J: Val->Ala mutations selectively alter helix-helix packing in the transmembrane segment of phage MI3 coat protein. Proc Natl Acad Sci USA 1993, 90: I I648-I I652.

63. Soto C, Castaño EM, Frangione B, Inestrosa NC: The a-helical to $b$-strand transition in the amino-terminal fragment of the amyloid b-peptide modulates amyloid formation. J Biol Chem 1995, 270:3063-3067.

64. Pilo P, Frey J, Vilei EM: Molecular mechanisms of pathogenicity of Mycoplasma mycoides subsp. mycoides SC. Vet J 2006, doi: I0.1016/j.tvjl.2006.10.016:.

65. Bals R, Weiner DJ, Wilson JM: The innate immune system in cystic fibrosis lung disease. J Clin Invest 1999, I 03:303-307.

66. Zabner J, Seiler MP, Launspach JL, Karp PH, Kearney WR, Look DC, Smith J], Welsh MJ: The osmolyte xylitol reduces the salt con- 
centration of airway surface liquid and may enhance bacterial killing. Proc Natl Acad Sci USA 2000, 97: I |6|4-1 I6I9.

67. Ganz T: Antimicrobial polypeptides. J Leukoc Biol 2004, 75:34-38

68. Mager S, Sloan J: Possible role of amino acids, peptides, and sugar transporter in protein removal and innate lung defense. Eur J Pharmacol 2003, 479:263-267.

69. Cheng X, Nicolet J, Poumarat F, Regalla J, Thiaucourt F, Frey J: Insertion element ISI296 in Mycoplasma mycoides subsp. mycoides small colony identifies a European clonal line distinct from African and Australian strains. Microbiology 1995, I 4I:322I-3228.

70. Altschul SF, Gish W, Miller W, Myers EW, Lipman DJ: Basic loca alignment search tool. J Mol Biol 1990, 21 5:403-4I0.

7I. Lin YC, Correia I, Ferronha MH, Shahram M, Miles R: Monitoring mycoplasma growth: A review with recent applications of tetrazolium reduction methods. In Mycoplasmas of ruminants: pathogenicity, diagnostics, epidemiology and molecular genetics - Vol. 5 Edited by: Poveda JB, Fernandez A, Frey J and Johansson KE. Brussels, European Communities; 200I:56-59.

72. Stelwagen K, Davis SR, Farr VC, Eichler SJ, Politis I: Effect of once daily milking and concurrent somatotropin on mammary tight junction permeability and yield of cows. J Dairy Sci 1994, 77:2994-300I.

73. Lacy-Hulbert SJ, Woolford MW, Nicholas GD, Prosser CG, Stelwagen $\mathrm{K}$ : Effect of milking frequency and pasture intake on milk yield and composition of late lactation cows. J Dairy Sci 1999, 82:1232-1239.

74. Abdo EM, Nicolet J, Frey J: Antigenic and genetic characterization of lipoprotein LppQ from Mycoplasma mycoides subsp. mycoides SC. Clin Diagn Lab Immunol 2000, 7:588-595.

Publish with Bio Med Central and every scientist can read your work free of charge

"BioMed Central will be the most significant development for disseminating the results of biomedical research in our lifetime. "

Sir Paul Nurse, Cancer Research UK

Your research papers will be:

- available free of charge to the entire biomedical community

- peer reviewed and published immediately upon acceptance

- cited in PubMed and archived on PubMed Central

- yours - you keep the copyright
BioMedcentral 